\title{
Impact of Islamic Ethics on cybersecurity policy in Iran
}

\author{
Diana I. Mullahmetova1 $₫$, Andrey A. Kudelin ${ }^{1,2} \mathbb{D}$ \\ ${ }^{1}$ National Research University - Higher School of Economics, \\ 20 Myasnitskaya ulitsa, Moscow, Russia, 101000 \\ ${ }^{2}$ Peoples' Friendship University of Russia (RUDN University), \\ 6 Miklukho-Maklaya St., Moscow, Russia, 117198 \\ $\triangle$ dimullakhmetova@edu.hse.ru
}

\begin{abstract}
This article tries to investigate whether there is an influence of Islamic Ethics on cybersecurity policy in Iran. It represents the government's approaches towards formulating cybersecurity policy in the country. Islamic Ethics is vital because it is a backbone of a good society. Every Muslim should conduct in accordance with Islamic law and must remember that all actions have certain consequences and man is in charge of his behavior. Therefore, people will be able to live in peace and there won't be need to be afraid of criminals. Many recent studies have focused on the problem of Islamic ethics and its influence on different aspects of life of Muslims. It seems interesting to explore the relationships between Islamic ethics and IT because IT gets deeper into people's life becoming the aspect that it is difficult - if not impossible - to imagine life without it nowadays. With the advent of information and communication technologies it is needed to concentrate on ethical foundations that are able to regulate cyberspace.
\end{abstract}

Key words: Quran, Sunnah, Sharia, Islam

Article history: Received: 11.09.2021. Accepted: 24.10.2021.

For citation: Mullahmetova DI., Kudelin AA. Impact of Islamic Ethics on cybersecurity policy in Iran. RUDN Journal of World History. 2022;14(1):33-42. DOI: 10.22363/2312-8127-2022$14-1-33-42$

\section{Влияние исламской этики на политику кибербезопасности в Иране}

\author{
Д.И. Муллахметова ${ }^{1} \bowtie$, А.А. Куделин ${ }^{1,2} \mathbb{D}$ \\ ${ }^{1}$ Национальный исследовательский университет «Высшая школа экономики», \\ 101000, Москва, Россия, Мясницкая улища, 20 \\ ${ }^{2}$ Российский университет дружбы народов, \\ 117198, Москва, Россия, ул. Миклухо-Маклая, 6 \\ $\triangle$ dimullakhmetova@edu.hse.ru
}

Аннотация. В статье рассматривается влияние исламской этики на политику кибербезопасности в Иране, также представлены подходы правительства к формулированию политики кибербезопасности в стране. Исламская этика жизненно важна, потому что это 
основа хорошего общества. Каждый мусульманин должен вести себя в соответствии с исламским законом и должен помнить, что все действия имеют определенные последствия и человек несет ответственность за свое поведение. Многие недавние исследования были сосредоточены на проблеме исламской этики и ее влиянии на различные аспекты жизни мусульман. Взаимосвязь между исламской этикой и информационными технологиями становится теснее, что в наши дни трудно представить жизнь без них. С появлением информационных и коммуникационных технологий необходимо сосредоточиться на этических основах, способных регулировать киберпространство.

Ключевые слова: Коран, сунна, шариат, ислам

История статьи: Поступила в редакцию: 11.09.2021. Принята к публикации: 24.10.2021.

Для цитирования: Mullahmetova D.I., Kudelin A.A. Impact of Islamic Ethics on cybersecurity policy in Iran // Вестник Российского университета дружбы народов. Серия: Всеобщая история. 2022. Т. 14. № 1. С. 33-42. DOI: 10.22363/2312-8127-2022-14$1-33-42$

\section{Introduction}

Islamic ethics are ethical rules and norms based on the Qur'an and the Sunnah of Prophet Muhammad. This concept implies person's relationship with society, God and oneself. It is important to mention that Islamic Ethics is an English translation of Arabic term. In Arabic it is pronounced as "akhlaq" (singular, khuluq) which means character and nature. By the way, the Arabic term "akhlaq" comprises two important meanings. The first one is related to the science ('ilm) that defines the right and wrong in human's conducts. In this case, ethic as science is aimed to investigate the principles of morality that should follow a man to conduct only good actions. The second one is connected to the meaning of "good character".

Shariah is considered as a code of conduct and morality of Muslims. This code intertwines both legal norms and religious institutions. Also, state and society are under control by Islamic law. Sharia is based on the Qur'an and the Sunnah - the basis of Islamic legislation. It is needed to distinguish Islamic and Human law because of Shariah's "divine origin which is based on divine revelations" [1. P. 508].

The Qur'an and the Sunnah are the fundamental and principal sources of Islamic Ethics, "Qur'an is the most significant source given by God for human being to refer to pertaining to human conduct besides the Sunnah of the Prophet Muhammad (p.b.u.h) as the role model to be imitated" [1. P. 508].

Nevertheless, there are some difficulties with some terms that stems from the fact that the Qur'an uses many notions in order to define the concept of moral principle, norms and religious goodness. For example, "al-khayr (goodness), al-birr (righteousness), al-qisr and al-iqsat (equity), al-adl (justice), al-haqq (truth and right), al-ma'ruf (known and approved), and al-taqwa (piety)". So, there are used a lot of versions which express the concepts of righteous and wrongness, goodness and divine justice. 


\section{Peculiarities of Islamic Ethics}

Islamic Ethics is an unusual phenomenon which has some features. Ethics becomes Muslim due to not only its source base but also architectonics that is characteristic for the entire Arab-Muslim culture. It is crucial feature that differ this term form others. Besides, it is needed to pay attention to the basic principle of Islamic Ethics which is contraposition - "zahir-batin". In this combination zahir can be translated as "explicit" or "external" and batin means "hidden" or "internal". Moreover, these concepts are not mutually exclusive, but, firstly, presuppose each other and point to each other, and, secondly, do not compete in significance together. This situation is ensured by the presence of the third element in the indicated principle, namely, the process that realizes the connectivity of 2 states, hidden and explicit, the transition from zahir to batin and vice versa.

This model helps to determine that Muslim ethics is the science of how a person must behave. In other words, it does not describe reality but focuses on the norm. Besides, action (deed) becomes the key concept of Islamic Ethics which defines the process that bounds the external and internal.

In Arabic there are widely used terms "niyya" that means the intention, "hal" can be translated as state of the soul in order to define the internal and the meaning of "fil" is directly connected to the external action of a man. Besides, there is a strong connectivity between the internal intention "niyya" and external action "fil" by deed.

It is supposed that if an act from a Muslim point of view is absent or considered invalid, thus, there is not at least one component (intention or action). Also, it must be noted that the action can be influenced by numerous factors. As for the intention, it is hidden from the others and is available only for human.

That's why Islamic Ethics pay a lot of attention to the formation of intention. It has to be individual and man should have clear understanding of what is good and what is evil because only the good can be the direction of the intention. However, it can be possible if person is aware of the definition of good. All these factors led, firstly, to the special position of knowledge in the Islamic world, and, secondly, it gave an utilitarian orientation to Muslim ethics: every action of a Muslim must have an intention, moreover, with a focus on the good, and an aimless act will be regarded as a bad act.

Thus, the architectonics of Islamic ethics is aimed to build such system in which the fundamental principle of Arab-Muslim culture as a whole, namely, the possibility of transition between two metacategories - "Explicit" and "Hidden". At the same time, ethics are not a passive-contemplative but an active actor of society that forms a whole spectrum of movements in the relationship between God and man, man and community, as well as within the personality itself. Muslim ethics has a direct connection with the changing circumstances, responding to them, and sometimes determining some of them. So, Islamic Ethics is regarded as a distinct phenomenon in Arabic-Muslim culture that arisen due to its authoritative texts. This science imbued a wide range of aspects, concepts, ideas from the Muslim philosophy. "The value categories indicate that the ethics of Islam primarily seeks to strengthen interpersonal ties, it is not individualistic, but active social, supporting 
the most general and character traits of the Muslim ethnos, such as compliance and solidarity" [2. P. 24]. That's why this term can be considered as social one.

\section{Cyberspace and Islamic Ethics}

Islamic ethics has a long history and significance in the life of Muslims and it has certain impact on some aspects on Iranian society, especially on cyber space. It can be seen as an instrument that restricts possibilities of the Internet. Due to the fact that one of the key sources of Islamic Ethics is the Qur'an and there are some interpretations of appropriate behavior for Muslims. Internet content is limited for Iranian people. "Iran has an ancient culture with religious basis. People have limited access to the various cultural products available abroad. Many of these are considered immoral, while others may be in conflict with religious beliefs, and considered unlawful. In any case, these products should be filtered to be available to people and this is what the government tries to do" [3].

Intention of Iranian government to restrict the cyber space is justified from Islamic view. First of all, it tries to defend users from unwanted content in the internet. According to the Qur'an, people must not do a mischief with anybody. This action is forbidden. "Make an easy thing, do not make it burden for oneself, give peace and tranquility to the one, and do not spread hatred, revulsion and disgust among others" [4]. Mischief, libel cyberspace, crackers and viruses, theft of services and breaking privacy, scams and pyramids, forgery over the net, dirty pictures contradict with the principles of Islamic Ethics and the government makes efforts to preserve its elements in Iranian society in order to create and maintain "Islamic content".

It is important to mention that not only the government is trying to defend cyber space and Iranian users from unwanted content but also parents, leaders and teachers are responsible for reminding their children about significance of Islamic Ethics' principles in their lives. Nowadays the youth are very keen on using the Internet and they clearly see big possibilities of it. And it is necessary to prevent them from bad actions. "Parents' incumbent is to remind children to avoid immoral and harmful websites and items and visit beneficial sites and obtain true knowledge from the vast treasure of the internet. They can be true Muslims maintaining righteousness, Amana" [5. P. 209]. Besides, cyber space represents not only opportunities for valuable information and the possible place of anti-Islamic content but also as an element which is able to help to find out fast all news which referred to Muslim's issues, "such as the suffering of defenseless Ummah, misconception in Islam and contemporary Fiqh issues" [5. P. 210].

Thus, we see that Muslims must use Islamic ethics for Internet. It can be said that Islamic Ethics is a key component of cyber space in Iran because its elements (goodness, honesty, moral values, etc.) have a great impact on the users' activities and opportunities in the Internet and their behavior towards other people.

\section{The origins of Internet censorship in Iran}

Nowadays the problem of information security is of concern to all countries around the world due to the facts that the role of information in making many 
important strategic decisions has increased and the number of cyber users has also enlarged. Besides, this problem is much more acute in Islamic Republic of Iran.

When the internet became more popular in Iran, various media began to move there trying to avoid restrictions set by Press Law of 1986. To stop the spread of inappropriate content, Iranian government proclaimed that Press Law applies to all internet-based publications. This law guarantees that there will be no censure and government control, however, it limits the role of the press to "constructive criticism" based on "logic and reason and void of insult, humiliation and detrimental effects" [6].

Reports may only be published in pursuit of one of five "legitimate objectives" including "to campaign against manifestations of imperialistic culture... and to propagate and promote genuine Islamic culture and sound ethical principles" [6].

It is considered that social media is highly censored in Iran and - how major experts describe - this internet censorship is one of the toughest in the world [7]. It stems from that fact that sexual, anti-religious material, political websites, information on women's rights and even blogs (which does not prevent Iranians from blogging to a wide variety of audiences) are outlawed in the country. Most popular information sites are blocked in Iran, for instance, YouTube, Facebook, Twitter, Google + and hundreds of other ones, social networks, sports sites, news resources, online stores, etc. According to the constitution, "The public media must take their place in the process of development of the Islamic revolution, and must serve in the propagation of Islamic culture. Iranian social media is forced to exist within this framework today. In this sphere they must look for opportunities for a healthy exchange of differing ideas, and must rigorously refrain from the propagation and encouragement of destructive and anti-Islamic qualities" [8]. Everything should be accompanied with Islamic Ethics. According to Iranian Clergy Mohsen Qara'ti, the Internet must be used to spread knowledge about Qur'an which is believed to be the root of Islamic Ethics, "we should also use this space to propagate the culture and teachings of the Qur' an and the Ahl al-Bayt" [9]. Also, he emphasizes the importance of good behavior and perseverance of moral qualities in the cyberspace which are the key elements of Islamic Ethics.

One of the main Iranian government's steps in creating a halal content in the Internet is the project National Information Network that was proposed during the presidential term of Mahmoud Ahmadinejad (2005-2013). According to the Iranian news agency Mehr, "the NIN would create an environment that would be "in accordance with Iran's Islamic culture" [10]. The network is able to control, filter and in some cases even block unwanted content that could negatively affect the situation in country.

On the one hand, this project can reduce cybercrimes, unwanted content and strengthen cybersecurity in Iran. On the other hand, there are many concerns about NIN due to the limitations of this network for the Iranian users. Also, they claimed that "the main goal of the NIN is to cutoff Iranians from the world" [10]. Their apprehensions are understandable because there is the report of RSF (Reporters without borders) which unravels the real situation related to the censorship in Iran. 
They have provided a list of press freedom's 20 worst digital predators in 2020 - companies and government agencies which employ their technology in order to control the life of the citizens and "jeopardize their ability to get news and information" [11]. In addition, the government pursues a strict censoring policy on the network based on Deep Packet technology Inspection [12]. This technology is able to filter and block certain content that does not comply with Islamic norms. Iran borrowed this network and perfect idea of blocking certain content from China and South Korea, which have achieved significant and successful results in censoring their network. The Iranian authorities continued to block websites until 2008 and it was found out that more than 10 million sites were blocked since 2002 to 2008 . There were already 15000 websites blocked in 2018 because they were called "immoral" [13].

Moreover, in order to increase the efficiency of developing cyber space, special bodies were formed whose powers included strict monitoring of the network. One of the most important and influential structures in the information sphere is considered the Supreme Council of Cyberspace, established in 2012. This organization plays a pivotal role in regulation and filtering of the Internet space in the country. This structure operates under the leadership of Ayatollah Khamenei, and President Hassan Rouhani is considered the chairman. Also, the council subordinates several departments, such as the National Cyberspace Center, The Committee to Determine Instances of Criminal Content (CDICC) and cyber police (FATA). Each of the above bodies has its own responsibilities and controls a certain area in cyber space. For example, the National Cyber Center monitors the news of technological discoveries inside and outside the country. The Committee, in turn, determines what kind of content should be censored. The philosophy of cyber police organization (FATA) is "to ensure the security of this space and maintain moral and religious principles in it, as well as respecting human values and norms of society" [14]. Moral principles are the basis of Islamic Ethics. Therefore, it is clearly seen that the observation of principles Islamic Ethics is manifested in the mission of this structure.

The Committee also controls the content, network, in case of detection of violations by users. It also generates a certain list sites with inappropriate content, which is subsequently filtered by Ministry of Information and Telecommunication Technologies. They control 2 significant structures: the Telecommunication Infrastructure Company (TIC) who provides everything needed for a national data network, and the Data Communication Company of Iran (DCI) who is responsible for the quality of telecommunication technologies and Internet services.

It is also worth noting a weighty and special place of Islamic Revolutionary Guard Corps (IRGC) among structures and departments, regulating cyberspace. "The involvement of the IRGC in the ICT field is justified by the need to protect the country via the Internet from ideological interference from outside" [15]. This structure owns a consortium of private businesses and about $50 \%$ of the shares of the TIC. So, the IRGC has a great impact and power in the country, controlling not only the cyberspace in IRI. It is considered that this organization unites the supporters of Iranian Shiite leader Grand Ayatollah Khomeini and loyal to 
the Islamic revolution and Islamic principles. According to Article 150 of Iran's constitution, "The Islamic Pasdaran Revolution's Corps will serve in the capacity of protecting the Revolution and its achievements. The IRGC scope of the duties and responsibilities and its relationship with the national other armed forces, will be determined by law, with emphasis on fraternal cooperation and harmony among them" [8].

The IRGC controls the Iranian Cyber Army that consists of underground social activists and hackers. They are in charge of monitoring and hacking sites with anti-Islamic content. Thus, an extensive network of various departments is represented in Iran which responsible for regulating the network and providing "clean content". The government has given these bodies broad powers to ensure "cultural security". All measures are manifestation of the important and fundamental role of Islamic culture, Ethics, rules, etc. These organizations are aimed, first of all, to defend the country's ideology and its principles from extremist and non-Islamic ideas. Moreover, IRI took steps to create a "halal Internet" successfully in terms of bolstering cybersecurity, preventing crimes and searching for violators of the law. There is also a powerful legal framework of Islamic Ethics in the country.

One of the major and significant Iranian legal documents is the Constitution of the Islamic Republic of Iran. There are some laws, which connected to the freedom of expression in the press in this document in Articles 24, 26 and 27. For instance, "freedom of expression can be restricted if it is found to be detrimental to the fundamental principles of Islam or the rights of the public" (Articles 20 and 24) [8]. According to the 40th Article, "no person may exercise his own rights as a means of constraining others or violating the public interest" [8]. The preamble of the Constitution represents the main goal of media, "strictly refrain from diffusion and propagation of destructive and anti-Islamic practices" [8].

Thus, in these articles it is clear that Islam is a pivotal basis for social life in Iran. In addition, its principles dictate how to behave, to build relationships, to treat, etc. Moreover, there is a huge impact of its principles in cybersecurity policy in Iran because everything must correspond with the tenets of Islam even in cyberspace.

It is crucial to pay attention to the Press Law, which ratified on September 8, 2002. Basics of Islamic Ethics are obviously represented in these articles. For example, according to the 3rd Article, "the Press has the right to publish and bring to the public's attention the people's and the officials' views, constructive criticisms, suggestions, [and] explanations in accordance with Islamic values and society's interests" [6]. Therefore, this document is manifestation and propagation of Islamic values that aimed "to promote genuine Islamic culture and sound ethical principles" [6]. Besides, the 6th Article represents the prohibition of "publishing heretical articles which violate Islamic values and spreading material which harms the bases of the Islamic Republic" [6]. The media is totally under control strict and rigid laws that impose great restrictions on the press in Iran.

Another important legal document is the Penal Code (IPC) which plays an important role in providing punishments against crimes, disseminating non-Islamic ideas and values, lies and blasphemy provisions. This document was approved by 
the Islamic Consultancy Parliament on 30 July 1991 and ratified by the High Expediency Council on 28 November 1991. The IPC is also a manifestation of vindication of Islamic Ethics in IRI [16].

All mentioned legal documents are guardians of Islamic culture in society. These laws strictly confine the freedom of media, human rights and social activities.

The various types of restrictions that are demonstrated in the laws, constitution and official documents of the Islamic Republic of Iran were created under the influence of the rules of Islamic ethics and under the pretext of its importance for society. All sorts of restrictions and provisions on Islamic ethics in the constitution have freed the hands of the government to actively promote Islamic values in the country.

In this context it is very important to pay attention to the speech of Deputy of Analysis and Discourse Building of Basij Organization of University Professor and Higher Education Centers of Isfahan Province Farhad Nejad said that "it is necessary to explain and promote Islamic culture, Ethics and values to all sections of society in order to prevent any rudeness and insults in the virtual and political space of the country" [17]. Also, he stated that the dominant position of justice and good moral characteristics are able to lead to improving the content of cyber space. The Supreme Leader of IRI Ali Khamenei agreed with his words and claimed that it is crucial to save Islamic values in order to prevent bad things in the internet. Thus, the Iranian government employs not only laws, bodies for controlling cyberspace but also makes speech where is highly emphasized of importance Islamic Ethics in Iranian society and cyber space.

\section{Conclusion}

Islamic Ethics and its key principles are very significant in Iran. It is clearly seen in the constitution of IRI and other documents which define cybersecurity policy in the country. According to these laws Islamic principles are the bases of all relationships and activities in the country. On the one hand, they represent certain limitations for people. On the other hand, Islamic Ethics intends to show the users how to conduct in different situations and the importance of perseverance its bases in society.

Impact of Islamic Ethics is evident on cybersecurity policy and cyberspace in Iran due to the many factors. First of all, its principles and significance became a trigger for more controlling and filtering the cyberspace in the country. It can be seen in some mentioned projects. For example, National Network, SHOMA, etc. Undoubtedly, it is a great achievement of IRI in terms of innovations However, it is obvious that with the help of these projects the Iranian's activities in the internet is restricted.

Secondly, impact of Islamic Ethics is also seen in intensifying promotion of Islamic values in Iran. For instance, speeches of Iranian officials are very evident and highlight the importance Islamic culture and its concept in order to provide a health society. 


\section{References}

1. Rahim AA. Understanding Islamic Ethics and Its Significance on the Character Building. International Journal of Social Science and Humanity. 2013;3(6):508-513.

2. Smirnov AV. Etika i politicheskaya filosofiya. [Ethics and Political Philosophy]. M.: Institut Filosofii RAN; 2001. (In Russ.).

Смирнов А.В. Этика и политическая философия. М., 2001.

3. Omidi R., Shoraka M. The Internet in Iran. IEEE Technology and Society Magazine. 2002;21(1):28-32. Available from: https://www.researchgate.net/publication/3226615 The_Internet_in_Iran [Accessed 23.08.2021].

4. Obaidullah $\bar{M}$. Ethical views on internet usage: An Islamic perspective. Daily Sun. 2019 January 11. Available from: https://www.daily-sun.com/arcprint/details/363287/Ethicalviews-on-internet-usage:-An-Islamic-perspective/2019-01-11 [Accessed 23.08.2021].

5. Latt S., Akbar Shah M. Internet Usage from Islamic Perspective: A Preliminary Survey with First Year Medical Students, Kuantan Campus, Pahang 2015. International Journal on Recent and Innovation Trends in Computing and Communication. 2017;(5):207-213.

6. The Press Law. Available from: https://www.wipo.int/edocs/lexdocs/laws/en/ir/ir013en.pdf [Accessed 23.08.2021].

7. Fedotov A. Opyt regulirovaniya informacionnogo prostranstva v Irane. [Experience in Regulating the Information Space in Iran]. Digital Russia. 2020, November 5. Available from: https://d-russia.ru/opyt-regulirovanija-informacionnogo-prostranstva-v-irane.html [Accessed 23.08.2021] (In Russ.).

Федотов А. Опыт регулирования информационного пространства в Иране. DigitalRussia. 2020. 5 ноября. URL: https://d-russia.ru/opyt-regulirovanijainformacionnogo-prostranstva-v-irane.html (дата обращения: 23.08.2021).

8. Constitution of the Islamic Republic of Iran. Available from: https://www.wipo.int/ edocs/lexdocs/laws/en/ir/ir001en.pdf [Accessed 23.08.2021].

9. Faaliyat dar faza-ye majazi az manzar-e Qur'an. [Activity in Cyberspace from the Perspective of the Qur'an]. MehrNews. 2017, August 7. Available from: https://www.mehrnews.com/news/4044094 [Accessed 23.08.2021] (In Pers.).

10. Mausume Bakhshi Pur. Tarh-e Kalan va meamari-ye shabake-ye melli etelaat eblaq shod. [The Master Plan and Architecture of the National Information Network Were Announced]. Mehr news. 2021, October 21. Available from: https://www.mehrnews.com/ news/5052652 [Accessed 23.10.2021] (In Pers.).

11. RSF unveils 20/2020 list of press freedom's digital predators. Reporters without borders. 2020, March 12. Available from: https://rsf.org/en/news/rsf-unveils-202020-list-pressfreedoms-digital-predators [Accessed 23.08.2021].

12. Chao L., Rhoads C. Iran's Web Spying Aided By Western Technology. The Wall Street Journal. 2009, June 22. Available from: https://www.wsj.com/articles/SB124562668777335653 [Accessed 23.08.2021].

13. Iran steps up net censorship. BBC News. 2003, May 12. Available from: http://news.bbc.co.uk/2/hi/technology/3019695.stm [Accessed 23.08.2021].

14. Police FATA va vazayef-e an. [Police FATA and Its Duties]. Donya. 2017, May 5. يليس-فتا-و-وظايف-2070) Available from: https:/www.heyvalaw.com/web/articles/view/1407 آن.html [Accessed 23.08.2021] (In Pers.).

15. Ceshkovskaya Y.U. Nacionalnaya informacionnaya set $v$ Irane kak sposob zashchity ot kiberatak [Iran's National Information Network as a Defence Against Cyber Attacks]. Pir-centr, 2020. Available from: http://www.pircenter.org/media/content/files/14/ 15029729650.pdf [Accessed 23.08.2021] (In Russ.).

Цешковская Е.Ю. Национальная информационная сеть в Иране как способ защиты от кибератак. Пир-центр. 2020. URL: http://www.pircenter.org/media/content/files/ 14/15029729650.pdf (дата обращения: 23.08.2021). 
16. Islamic Penal Code of Iran. Available from: https://www.refworld.org/cgibin/texis/vtx/ rwmain/opendocpdf.pdf?reldoc=y\&amp;docid=52b812384 [Accessed 23.08.2021].

17. Tabyin-e Akhlaq-e Resaneyi Maneyi Hattaki Dar Faza-ye Majazi va Siyasi Mishavad. [Media Ethics Prevents Insults in Cyberspace and Politics]. 2016, February 19. Available from: https://www.irna.ir/news/84210960 [Accessed 23.08.2021] (In Pers.).

\section{Информация об авторах:}

Муллахметова Диана Ильдаровна - магистрант факультета мировой экономики и мировой политики Высшей школы экономики, e-mail: dimullakhmetova@edu.hse.ru

Куделин Андрей Александрович - кандидат исторических наук, доцент кафедры всеобщей истории Российского университета дружбы народов, доцент Школы востоковедения факультета мировой экономики и мировой политики Высшей школы экономики, e-mail: kudelin-aa@rudn.ru. ORCID: 0000-0002-4294-5032

\section{Information about the authors:}

Mullakhmetova Diana Ildarovna - graduate student of the Faculty of World Economy and International Affairs (HSE University), e-mail: dimullakhmetova@edu.hse.ru

Kudelin Andrey Aleksandrovich - PhD. in History, assistant professor of Department of world history, assistant professor of School of Asian Studies, Faculty of World Economy and International Affairs (HSE University), e-mail: kudelin-aa@rudn.ru. ORCID: 0000-00024294-5032 